\title{
Effects of essential oils of Cashew and Castor on intake, digestibility, ruminal fermentation and purine derivatives in beef cattle fed high grain diets
}

\author{
Efeito de óleos essenciais de Caju e Mamona sobre a ingestão, \\ digestibilidade, fermentação ruminal e derivados de purina em \\ bovinos de corte alimentados com dietas alto grão
}

\author{
Sabrina Marcantonio Coneglian ${ }^{1 *}$; Roman David Castañeda-Serrano ${ }^{2 *}$; Olga Teresa \\ Barreto $\mathrm{Cruz}^{2}$; Antonio Ferriani Branco ${ }^{3}$
}

\begin{abstract}
The objective of this study was to determine the effects of essential oils of Anacardium occidentale (Cashew) and Ricinus communis (Castor) on intake, digestibility, ruminal fermentation and excretion of purine derivatives in beef cattle fed high grain diets. Five Nellore steers fitted with ruminal cannula were used in a $5 \times 5$ Latin square design ( 21 days period). The treatments were control MON $(0.2 \mathrm{~g}$ monensin animal day ${ }^{-1}$ ) and 1, 2, 4 and $8 \mathrm{~g} \mathrm{EO}$ animal day ${ }^{-1}$ (Essential oils - Oligobasics ${ }^{\circledR}$ ). All the animals had a basal diet, corn silage-based total mixed ration (TMR) of 80:20 concentrate:forage ratio. Intake, digestibility, ruminal fermentation and excretion of purine derivatives were determined over five consecutive days in each period. Intake and digestibility of dry matter (DM), neutral detergent fibre $(\mathrm{NDF})$ and crude protein $(\mathrm{CP})$ were not influenced by treatments $(\mathrm{P}>0.05)$. However, increasing levels of EO showed a quadratic effect $(\mathrm{P}<0.014)$ above $2 \mathrm{~g}_{\text {animal }} \mathrm{day}^{-1}$ on the ruminal $\mathrm{pH}$. The excretion of allantoin and uric acid were not influenced by the treatments $(\mathrm{P}>0.05)$, but levels above $2 \mathrm{~g}$ day decreased the synthesis of microbial proteins $(\mathrm{P}<0.05)$. It is concluded that the $\mathrm{EO}$ of $A$. occidentale and $R$. comunnis effectively controlled ruminal fermentation as well as sodium monensin at the studied levels. EOs have the potential to be used in place of monensin in the studied levels.
\end{abstract}

Key words: Additives. Antibiotics. Bioactive compounds. Ionophores. Monensin. Plant extracts.

\section{Resumo}

O objetivo deste estudo foi determinar o efeito dos óleos essenciais de Anacardium occidentale (Caju) e Ricinus communis (Mamona) sobre a ingestão, digestibilidade, fermentação ruminal e excreção de derivados de purina em bovinos de corte alimentados com dietas alto grão. Cinco novilhos da raça Nelore, com cânula ruminal, foram utilizado um delineamento quadrado latino $5 \times 5$ (período de 21 dias). Os tratamentos foram controle MON (0,2 g monensina animal dia $\left.^{-1}\right)$ e $1,2,4$ e $8 \mathrm{~g} \mathrm{OE}$ animal dia $^{-1}$ (óleos essenciais - Oligobasics ${ }^{\circledR}$ ). Todos os animais foram alimentados com uma dieta basal 20:80 volumoso: concentrado. Ingestão, digestibilidade, fermentação ruminal e excreção de derivados de purina foram determinados ao longo de cinco dias consecutivos em cada período. A ingestão e a

Dra , Zootecnia, Especialista Técnica, Mosaic Fertilizantes, São Paulo, SP, Brasil. E-mail: sabrina.coneglian@valefert.com

2 Investigadores, Grupo de Investigación en Sistemas Agroforestales Pecuarios, Departamento de Producción Animal, Universidad del Tolima, Ibagué, Tolima, Colombia. E-mail: rcastaneda@ut.edu.co; otbarretoc@ut.edu.co

3 Dr., Zootecnia, Departamento de Zootecnia, Universidade Estadual de Maringá, UEM, PR, Brasil. E-mail: afbranco@uem.br

* Author for correspondence 
digestibilidade da matéria seca (MS), fibra em detergente neutro (FDN) e proteína bruta (PB) não foram influenciadas pelos tratamentos $(\mathrm{P}>0,05)$. No entanto, níveis crescentes de $\mathrm{OE}$ apresentaram efeito quadrático $(\mathrm{P}<0,014)$ acima de $2 \mathrm{~g}$ animal dia ${ }^{-1}$ no $\mathrm{pH}$ ruminal. A excreção de alantoína e ácido úrico não foi influenciada pelos tratamentos $(\mathrm{P}>0,05)$, mas níveis acima de $2 \mathrm{~g} \mathrm{dia}^{-1}$ diminuíram a síntese de proteínas microbianas $(\mathrm{P}<0,05)$. Conclui-se que o $\mathrm{OE}$ de $A$. occidentale e $R$. comunnis controlam efetivamente a fermentação ruminal, assim como a monensina sódica, nos níveis estudados, podendo substituir a monensina nos níveis estudados.

Palavras-chave: Aditivos. Antibióticos. Compostos bioativos. Ionóforos. Monensina. Extratos vegetais.

\section{Introduction}

To improve the productivity in high performance animals is necessary the inclusion of grain in diets. However, in high grain diets the use of additives is necessary to avoid ruminal acidosis. Antibiotics as ionophores have an essential role worldwide to improve feed conversion, decrease methane production (STEINFELD et al., 2006) and control ruminal fermentation in high grain diets to prevent subacute ruminal acidosis (SARA) (RUSSELL; STROBEL, 1989; KRAUSE; OETZEL, 2006). One example is monensin sodium, which has had a proven effect on ruminal fermentation (BERGEN; BATES, 1984; MCGUFFEY et al., 2001). However, to avoid the negative effect of antibiotics, is necessary explore if biocompounds of plants present in the essential oils (EO) can enhance the ruminal fermentation. Antibiotics as regulators of ruminal fermentation can generate residues, with detrimental effects on humans, such as resistance to antibiotics (KHACHATOURIANS, 1998; VAN DEN BOGAARD; STOBBERINGH, 2000; DEWULF et al., 2007; DODDS, 2017; GRENNI et al., 2018, JUTKINA et al., 2018). The bioactive compounds of plants present in the essential oils are an alternative for the control of ruminal fermentation (MEDJEKAL et al., 2017; SOLTAN et al., 2018a). The essential oils (EO) contain secondary metabolites with a modulating effect at rumen fermentation (YANG et al., 2007; BENCHAAR et al., 2008; SOLTAN et al., 2018b). Bioactive compounds of tropical plants have shown a positive effect in methane depression by up to $25 \%$, without negatively affecting digestibility
(MEDJEKAL et al., 2017; SOLTAN et al., 2018a) and ruminal modulation (BABAYEMI et al., 2004; KHOLIF et al., 2018), due to bioactive compounds with antimicrobial effects (AUMEERUDDYELALFI et al., 2016). The mechanisms that confer EO their antimicrobial properties are still not well understood (LAMBERT et al., 2001) with evidence of change to the bacterial cell membrane due to changes in electron transport and the ion gradient, in the translocation of proteins, phosphorylation and other enzyme-dependent reactions, similar to ionophores (BURT, 2004). Thus, considering the varied range of chemical compounds present in oils, antimicrobial activity may not be mediated by a single specific mechanism, with synergy between modes of action (BAKKALI et al., 2008). The use of EO in mixture can provide potentiated effect. Antimicrobial properties have been described for A. occidentale (Cashew) and R. communis (Castor) (VIEIRA et al., 2001; MUROI et al., 2004; TREVISAN et al., 2006). Several phenolic compounds and terpenes have been identified in $A$. occidentale, such as cardol, cardonol $\beta$-ocimeno, $\alpha$-copaeno and $\delta$-cadineno (MAIA et al., 2000; ATTANASI et al., 2009; LOMONACO et al., 2009) with antimicrobial activity (HIMEJIMA; KUBO, 1991; NAGABHUSHANA et al., 1995; KUBO et al., 2003) mainly on gram positive bacteria, (MUROI; KUBO, 1993). Controlling Gram positives lactate-producing (Streptococcus bovis), lactate rate production decrease, allowing growth of lactic acid - utilizing bacteria (Selenomonas ruminantium y Megasphaera elsdenii), because the rate of use of lactate usually exceed his production (BELANCHE et al., 2012). Several compounds 
with antimicrobial and anti-fungal activity have been associated with $R$. communis (RIBEIRO et al., 2016), such as $\alpha$-thujone and 1,8-cineole, $\alpha$-pinene camphor and camphene (KADRI et al., 2011; JENA; GUPTA, 2012; ZARAI et al., 2012). The objective of this study was to determine the effects of EO of $A$. occidentale and $R$. communis in mixture on intake, digestibility, ruminal fermentation and excretion of purine derivatives in beef cattle fed high grain diets.

\section{Material and Methods}

\section{Animals, experimental design, and diets}

Five Nellore steers fitted with ruminal cannula with an average body weight (BW) of $270 \pm 34$ $\mathrm{kg}$, housed in individual pens, were fed twice a day with free access to water. A 5x5 Latin square design was used over five periods (21 days each one). All the animals were fed whit the same basal diet containing $16.4 \mathrm{~g} \mathrm{~kg}-1$ of crude protein (CP) and $79.0 \mathrm{~g} \mathrm{~kg}-1$ total digestible nutrients (TDN) on a dry matter (DM) basis according to NCR requirements. This constituted of $20 \mathrm{~g} \mathrm{~kg}-1$ of corn silage and $80 \mathrm{~g} \mathrm{kg-1}$ of concentrate corn grain ground, soybean meal, urea and minerals) (Table 1). The Essential-Oligobasics ${ }^{\circledR}$, containing $11 \%$ of cardol, $20 \%$ of cardanol and $9 \%$ of ricinoleic acid, were placed daily on concentrate. Both oils were produced in Northern Brazil. Vermiculite was used for the solidification of the essential oils formulated by Oligo Basics Agroindustrial Ltd ${ }^{\circledR}$ (Cascavel, Brazil). The treatments were offered to ensure intake of the following amounts of monensin $(\mathrm{MON})$ and EO (Essential oils - Oligobasics $\left.{ }^{\circledR}\right)$ : 1. 0.2 MON g-1;2. 1 g EO g-1; 3.2 g EO g-1; 4.4 g EO g-1 and $5.8 \mathrm{~g}$ EO g g-1.

Table 1. Chemical composition of the total mix ration (TMR) and perceptual composition of ingredients used in the experimental basal diet.

\begin{tabular}{lc}
\hline & $\%$ of DM \\
\hline Ingredient & 20.00 \\
Corn Silage & 62.18 \\
Corn grain, ground & 14.84 \\
Soybean meal & 0.74 \\
Urea & 0.47 \\
Dicalcium phosphate & 0.94 \\
Limestone & 0.83 \\
Mineral mixture ${ }^{1}$ & \\
Chemical composition & 76.99 \\
Dry matter & 16.35 \\
Crude protein & 21.95 \\
Neutral detergent fibre & 3.40 \\
Ether extract & 79.0 \\
Total digestible nutrients & \\
\hline
\end{tabular}

${ }^{1}$ Calcium: 130.0g (max.), Phosphorus: 65.0g (min.), Sodium: 135.0g, Sulfur: 12.0g, Magnesium: 12 g, Manganese: 1.050 mg, Cobalt: $63 \mathrm{mg}$, Iodine: $63 \mathrm{mg}$, Copper: $1.155 \mathrm{mg}$, Selenium: $18 \mathrm{mg}$, Zinc: $3.080 \mathrm{mg}$ and Fluor: $650 \mathrm{mg}$. 


\section{Intake and digestibility}

Diets were offered twice daily (am/pm). Intake was recorded daily by weighing all the feeds offered and orts left by the steers allow approximately 5\% orts. 500 gr of samples of feed ingredients and orts left over were collected daily and were conserved at $-20{ }^{\circ} \mathrm{C}$ until it was processed by pre-drying in a forced ventilation oven at $55^{\circ} \mathrm{C}$ for 72 hours, milled at $1 \mathrm{~mm}$. The experimental periods lasted for 21 days, with the last four days of each period being used to collect at morning samples of feeds, leftovers, ruminal fluid, faeces and urine samples. An external indicator containing chromium oxide to estimate faecal output was placed with the concentrate in the morning feed, at a daily dose of $10 \mathrm{~g}-1$ per animal, from the 7 th day of each experimental period. Faecal samples $(50 \mathrm{~g})$ in the rectal ampulla, were collected on days 18 and 20 of each experimental period, twice daily at alternate times with 4-hour intervals. The chemical composition was determined using AOAC (2016) methods in dry matter number 930.15, crude protein number 992.15 and ether extract number 920.39, and neutral detergent fibre was determined according to Van Soest et al. (1991) with modification of (MERTENS, 2002). Faecal chromium was determined by atomic absorption spectrophotometry (WILLIAMS et al., 1962) and then used together with the nutrient concentration to determine the flow of nutrients in the faeces (SMITH; REID, 1955). The TDN was calculated according to the equations proposed by Sniffen et al. (1992and the yields are adjusted for maintenance requirements $(.05 \mathrm{vs} .150 \mathrm{~g}$ of cell dry weight per gram of carbohydrate fermented per hour for SC and NSC bacteria, respectively).

\section{Ruminal fermentation}

Ruminal fluid was collected through ruminal cannula manually within the rumen at 2, 4, 6 and $8 \mathrm{~h}$ after the first feeding. Samples of $150 \mathrm{~mL}$ were withdrawn. The $\mathrm{pH}$ of the ruminal fluid was measured immediately after sampling (Digimed
DM20 $\mathrm{pH}$ meter). Samples of $50 \mathrm{~mL}$ were acidified with $50 \% \mathrm{H} 2 \mathrm{SO} 4(1: 1)$ and frozen at -20 ${ }^{\circ} \mathrm{C}$ for later determination of voltaic fatty acids (VFA) and ammonia $\mathrm{N}(\mathrm{NH} 3-\mathrm{N})$ concentrations (SANTSCHI et al., 2005). Rumen fluid was taken from the middle part of the rumen by a stomach tube connected to a vacuum pump and then filtered through layers of cheesecloth. The concentration of NH3-N of samples was measured by a calorimetric method according to Chaney and Marbach (1962). About $30 \mathrm{~mL}$ were centrifuging a $10 \mathrm{ml}$ sample for $15 \mathrm{~min}$ at $4000 \mathrm{xg}$. To $5 \mathrm{ml}$ supernatant, $1 \mathrm{ml}$ of $250 \mu 1$ metaphosphoric acid was added. After 30 min, if a precipitate formed, it was removed by a brief centrifuging. The determination of VFA was made in GLC (Hewlett Packard 5890 Series II GC) according methodology of Playne (1985).

\section{Purine derivatives}

Sample spots of urine were collected on days 19 and 20 of each experimental period, 3 to $4 \mathrm{~h}$ after the first feeding, during spontaneous urination. Samples of $15 \mathrm{~mL}$ were diluted in $135 \mathrm{~mL}$ of $\mathrm{H} 2 \mathrm{SO} 4$ with $0.036 \mathrm{~N}$ (CHEN et al., 1995) and adjusted to a $\mathrm{pH}$ of less than 3 to avoid bacterial destruction of purine derivatives, these were then stored at $-20{ }^{\circ} \mathrm{C}$. The total daily urine volume was estimated according to the creatinine concentration $(\mathrm{mg} / \mathrm{L})$ in the urine spot sample. This volume was then used to estimate the daily excretions of allantoin and uric acid from each animal. The uric acid, xanthine and hipoxantine analyses were perform according (CHEN et al., 1990). The urine allantoin analyses were performed using the colorimetric method (FUJIHARA et al., 1987; CHEN; GOMES, 1992). Estimates of creatinine and uric acid concentrations in urine were performed using commercial Labtest ${ }^{\circledR}$ kits.

\section{Statistical analysis}

The experimental design was a $5 \times 5$ Latin Square. An ANOVA was performed using the mixed 
model methodology in MINITAB 17'TM (2014). For variables that were repeated over time, a splitplot arrangement was used (subdivided plots), considering the effect of time and the interaction between time and treatment. The effects of inclusion levels of $A$. occidentale and $R$. communis were analysed by polynomial regression models. Monensin was compared with each level of EO by the Tuckey test. The mathematical model used included period, treatment and animal effects, which were considered as random: $\mathrm{Yijk}=\mu+\mathrm{Ai}+\mathrm{Pj}+\mathrm{Tk}$ + eijk, where $\mu=$ mean of treatments; $\mathrm{Ai}=$ effect of animal $\mathrm{i}$, ranging from 1 to $5 ; \mathrm{Pj}=$ effect of period $\mathrm{j}$, ranging from 1 to 5 ; $\mathrm{Tk}=$ effect of treatment $\mathrm{k}$, ranging from 1 to 5 ; eijk = random error. Significant differences were accepted if $\mathrm{P} \leq 0.05$.

\section{Results}

No differences were observed in intake and digestibility of dry matter (DM), neutral detergent fibre (NDF), crude protein (CP), ether extract (EE) and non-fibre carbohydrates (NFC), between the use of EO and monensin (Table 2). No differences were observed for the inclusions of $\mathrm{EO}(\mathrm{P}>0.05)$.

Table 2. Intake, and digestibility in beef cattle supplemented with Monensin and levels of Essential Oils of $A$. occidentale and $R$. communis.

\begin{tabular}{|c|c|c|c|c|c|c|c|c|}
\hline \multirow{2}{*}{ Item } & \multirow{2}{*}{$\mathrm{MON}^{1}$} & \multicolumn{4}{|c|}{${ }^{+} \mathrm{EO} \mathrm{g} \mathrm{day}^{-1}$} & \multirow{2}{*}{$\mathrm{SEM}^{2}$} & \multicolumn{2}{|c|}{ P-Value } \\
\hline & & 1 & 2 & 4 & 8 & & Linear & Quadratic \\
\hline \multicolumn{9}{|l|}{ Intake, $\left(\mathrm{kg}\right.$ day $\left.^{-1}\right)$} \\
\hline Dry matter & 6.32 & 6.39 & 6.98 & 6.70 & 6.50 & 0.95 & 0.80 & 0.59 \\
\hline Neutral detergent fibre & 1.59 & 1.56 & 1.77 & 1.66 & 1.63 & 0.23 & 0.95 & 0.67 \\
\hline Crude protein & 1.09 & 1.09 & 1.20 & 1.15 & 1.12 & 0.17 & 0.89 & 0.60 \\
\hline Ether extract & 0.17 & 0.18 & 0.19 & 0.18 & 0.18 & 0.03 & 0.62 & 0.92 \\
\hline Non-fibre carbohydrates & 3.11 & 3.19 & 3.43 & 3.33 & 3.21 & 0.47 & 0.71 & 0.53 \\
\hline \multicolumn{9}{|l|}{ Digestibility, $\left(\mathrm{g} \mathrm{kg}^{-1}\right)$} \\
\hline Dry matter & 688.8 & 580.1 & 686.2 & 654.0 & 580.6 & 4.25 & 0.67 & 0.43 \\
\hline Neutral detergent fibre & 582.3 & 436.1 & 604.2 & 560.3 & 449.5 & 6.42 & 0.73 & 0.42 \\
\hline Crude protein & 660 & 521.1 & 632.9 & 651.3 & 588.8 & 5.28 & 0.77 & 0.28 \\
\hline Ether extract & 717.5 & 644.8 & 760.6 & 734.9 & 612.1 & 3.91 & 0.52 & 0.34 \\
\hline Non-fibre carbohydrates & 780.9 & 720.6 & 767 & 714.2 & 667.9 & 4.64 & 0.19 & 0.71 \\
\hline $\mathrm{TDN}^{3}$ & 720.1 & 645.1 & 739.9 & 704.8 & 620.4 & 4.12 & 0.50 & 0.42 \\
\hline
\end{tabular}

$1 \mathrm{MON}=0.2 \mathrm{~g}$ day-1 Monensin; 2SEM: standard error of means. $3 \mathrm{TDN}=$ total digestible nutrients. + Essential oil containing $11 \%$ of cardol, $20 \%$ of cardanol and $9 \%$ of ricinoleic acid.

In ruminal fermentation, the $\mathrm{pH}$ was affected by EO inclusion $(\mathrm{P}<0.05)$ (Table 3$)$. Ruminal concentrations of ammonia (N-NH3) were not influenced by the treatments (Table 3). No effect was observed for VFA with any inclusion level of EO $(\mathrm{P}<0.05)$ (Table 3). The ruminal concentration of VFA not was influenced by EO, with acetate:propionate:butyrate molar ratios close to 50:35:15, respectively (WATKINS et al., 2013). 
Table 3. Ruminal fermentation in beef cattle supplemented with Monensin and increasing levels of essential oils of A. occidentale and $R$. communis.

\begin{tabular}{|c|c|c|c|c|c|c|c|c|}
\hline \multirow{2}{*}{ Item } & \multicolumn{5}{|c|}{${ }^{+}$EO Inclusions $\mathrm{g}$ day ${ }^{-1}$} & \multirow{2}{*}{$\mathrm{SEM}^{2}$} & \multicolumn{2}{|c|}{ P-Value } \\
\hline & $\mathrm{MON}^{1}$ & 1 & 2 & 4 & 8 & & Linear & Quadratic \\
\hline $\mathrm{pH}$ & 6.35 & 6.70 & 6.68 & 6.53 & 6.16 & 0.11 & 0.527 & 0.014 \\
\hline $\mathrm{NH}_{3}-\mathrm{N}, \mathrm{mg} / 100 \mathrm{~mL}$ & 22.73 & 23.16 & 22.05 & 22.75 & 23.15 & 2.09 & 0.835 & 0.353 \\
\hline VFA, mM/L & & & & & & & & \\
\hline Acetate & 48.56 & 56.09 & 48.90 & 50.07 & 49.81 & 2.57 & 0.358 & 0.307 \\
\hline Propionate & 27.01 & 59.09 & 48.90 & 50.07 & 49.81 & 3.93 & 0.596 & 0.863 \\
\hline Butyrate & 15.38 & 28.93 & 34.22 & 29.64 & 33.17 & 1.14 & 0.169 & 0.929 \\
\hline Acetate:Propionate & 2.10 & 2.31 & 2.04 & 2.37 & 2.25 & 0.21 & 0.863 & 0.796 \\
\hline
\end{tabular}

$1 \mathrm{MON}=0.2 \mathrm{~g}$ day-1 Monensin; 2SEM: standard error of means. +Essential oil containing $11 \%$ of cardol, $20 \%$ of cardanol and $9 \%$ of ricinoleic acid.

Intake, blood nitrogen, daily excretions Nevertheless, faecal excretion of $\mathrm{N}$ and efficiency of of allantoin, uric acid and purines, were also microbial protein synthesis (EMPS) were affected not affected by the inclusion of EO (Table 4). by EO levels.

Table 4. Excretion of urinary purine derivatives (PD), and microbial N supply in cattle supplemented with Monensin and increasing levels of essential oils of $A$. occidentale and $R$. communis.

\begin{tabular}{|c|c|c|c|c|c|c|c|c|}
\hline \multirow{2}{*}{ Item } & \multirow{2}{*}{$\mathrm{MON}^{1}$} & \multicolumn{4}{|c|}{ EO Inclusions g day ${ }^{-1}$} & \multirow{2}{*}{$\mathrm{SEM}^{2}$} & \multicolumn{2}{|c|}{ P-Value } \\
\hline & & 1 & 2 & 4 & 8 & & Linear & Quadratic \\
\hline $\mathrm{BUN}^{3}, \mathrm{mg} \mathrm{dl}$ & 15.3 & 13.4 & 14.4 & 15.4 & 15.0 & 1.6 & 0.131 & 0.237 \\
\hline $\mathrm{N}$ intake, $\mathrm{g}_{\text {day }}{ }^{-1}$ & 174.9 & 174.9 & 191.5 & 184.0 & 179.2 & 26.8 & 0.907 & 0.326 \\
\hline Faecal N, g day ${ }^{-1}$ & 56.3 & 76.6 & 61.8 & 61.5 & 72.1 & 5.5 & 0.764 & 0.040 \\
\hline Allantoin excretion, mmol day ${ }^{-1}$ & 237.2 & 186.9 & 234.9 & 246.4 & 165.6 & 47.5 & 0.824 & 0.122 \\
\hline Uric acid excretion, mmol day ${ }^{-1}$ & 2.7 & 2.4 & 3.3 & 2.4 & 2.2 & 0.7 & 0.562 & 0.525 \\
\hline $\mathrm{PD}^{4}, \mathrm{mmol}_{\text {day }}{ }^{-1}$ & 239.9 & 189.3 & 238.2 & 248.7 & 167.7 & 48.0 & 0.819 & 0.115 \\
\hline Microbial protein, $\mathrm{g} \mathrm{N}$ day ${ }^{-1}$ & 186.3 & 142.4 & 184.6 & 193.9 & 124.3 & 41.1 & 0.825 & 0.116 \\
\hline $\mathrm{EMPS}^{5}, \mathrm{~g} \mathrm{~N} \mathrm{~kg}$ TDN & 238.8 & 176.7 & 239.7 & 239.2 & 163.7 & 51.5 & 0.873 & 0.024 \\
\hline
\end{tabular}

$1 \mathrm{MON}=0.2 \mathrm{~g}$ day-1 Monensin; 2SEM: standard error of means. 3BUN: Blood urea nitrogen; 4PD: Purine derivates; 5EMPS = efficiency of microbial protein synthesis. +Essential oil containing $11 \%$ of cardol, $20 \%$ of cardanol and $9 \%$ of ricinoleic acid.

\section{Discussion}

In this study the EO had been a similar effect as monensin in the fermentation, without negatively affecting intake or digestibility.

These results are similar to Barreto et al. (2014), who evaluated the inclusion of a mixture of EO from $R$. communis and A. occidentale at $3 \mathrm{~g}$ day-1 in crossbred bulls, and found no negative effect on intake and digestibility.

EO has a similar effect to monensin (CHAO et al., 2000; GOÑI etal., 2009), which exerts its antimicrobial activity on Gram positive bacteria, acting on the lipid membrane where they accumulate (BENCHAAR; GREATHEAD, 2011). They exert their antimicrobial 
effect by altering the permeability of the membrane, interrupting the transport processes of the cells and the interaction with the membrane proteins and other cytoplasmic components (KHORSHIDIAN et al., 2018). EO can improve feed efficiency in a similar way to monensin (MCGUFFEY et al., 2001; BUSQUET et al., 2006; CASTILLEJOS et al., 2006; BENCHAAR et al., 2008).

In beef cattle, Benchaar et al. (2006) evaluated the effects of dietary addition of monensin $(33 \mathrm{mg}$ $\mathrm{kg}^{-1} \mathrm{DM}$ ) and different doses of a mixture of EO (2, 3 and $4 \mathrm{~g}$ day-1) with thymol, eugenol, vanillin and limonene, and observed that DM intake and feed efficiency (ADG to DM intake ratio) were not affected $(P>0.05)$ by addition of EO, but that $\mathrm{EO}$ had a quadratic effect $(P<0.05)$, which was highest at the dose of 2 gday $^{-1}$.

More doses need to be tested, lower doses may have no effect, or the higher doses may have a deleterious effect in ruminal population for the antimicrobial effect of the EO.

In this experiment, different levels of EO showed a quadratic effect $(\mathrm{P}<0.014)$ with the inclusions of EO above $2 \mathrm{~g}^{-1}$ animal. The ruminal $\mathrm{pH}$ remained at an average of 6.48 , which is considered high given the high percentage of grains in the diet (80\%), demonstrating that both monensin and EO of $A$. occidentale and $R$. communis were efficient in controlling the ruminal acidity. When ruminants are grazing, the $\mathrm{pH}$ remains close to neutrality. However, when diets contain large amounts of cereals or grains, the high fermentation rate can lower the $\mathrm{pH}$ dramatically, contributing to the appearance of acidosis.

Similar effects have been reported by Benchaar et al. (2006), who observed decreased $\mathrm{pH}$ values in cows supplemented with $2 \mathrm{~g}^{\mathrm{day}^{-1}}$ of a compound with several essential oils (Crina Ruminants ${ }^{\circledR}$ ) compared to animals without supplementation; these values were between 6.4 and 6.3, which are similar to values found in the present study. Evans and Martin (2000) also reported an in vitro experiment where the addition of $400 \mathrm{mg} \mathrm{L}^{-1}$ thymol ruminal liquid increased the $\mathrm{pH}$ over 24 hours, yet no effect was observed at lower doses of 50, 100 and $200 \mathrm{mg} \mathrm{L}^{-1}$.

In the present study, levels above $2 \mathrm{~g} \mathrm{EO}$ day $^{-1}$ had a quadratic effect on $\mathrm{pH}$. These results indicate that $\mathrm{EO}$ of $A$. occidentale and $R$. communis may have strong antimicrobial activity and lower doses. Patra and Yu (2012) evaluated five EO - clove, eucalyptus, garlic, oregano and mint - in different levels in three doses in vitro $(0,25,0.50$ and $1.0 \mathrm{~g}$ $\mathrm{L}^{-1}$ ) and found negative effects on the digestibility of DM and fibre in the high doses, possibly due to a negative effect on ruminal populations, since EO decreased the abundance of archaea, protozoa and cellulolytic bacteria. However, bacterial diversity in low and medium doses increase for all EO, except for oregano. They concluded that the effectiveness of EO may be greater at lower doses and as a mixture of EO.

In the present study, the ruminal ammonia concentrations were similar to $\mathrm{MON}$, and not influenced by EO inclusion levels $(\mathrm{P}>0.05)$. Observations on the efficiency of the use of EO in reducing the number of hypper-ammonia bacteria, the rate of deamination and consequently the rate of ammonia production, with a corresponding increase in the amount of by-pass protein reaching the small intestine were described (ANDO et al., 2003; MCINTOSH et al., 2003; CASTILLEJOS et al., 2007; SZUMACHER-STRABEL; CIEŚLAK, 2012). Ahmed et al. (2014) conducted in vitro and in vivo experiments to investigate the potential impacts of different levels of an EO mixture (eucalyptus, cinnamon, mint, thyme and lemon) in three treatments, $0,0.5$ and $1 \mathrm{~mL} \mathrm{EO} \mathrm{day}{ }^{-1}$, and found a decrease in the digestibility of $\mathrm{CP}$ without negative impacts on ruminal parameters.

The ruminal concentration of VFA not was influenced by the treatments, probably because the animals was adapted to use of EO. The concentrations and proportions of VFA are not always affected by 
the inclusion of EO (BEAUCHEMIN; MCGINN, 2006; NEWBOLD et al., 2004). It is likely that the production and proportion of VFA in the rumen depends on the diet of the animals (BENCHAAR et al., 2008). Data on the effects of EO on VFA are variable, because the ruminal microorganisms can adapt to the use of EO (BENCHAAR, et al., 2008). Soltan et al. (2018b), in canulated sheep with a diet of 50:50 Concentrate:Forage with a microencapsulated blend of EO (cinnamaldehyde, eugenol, carvacrol, and capsicum oleoresin) in three treatments control, $200 \mathrm{mg}$ EO and $400 \mathrm{mg}$ EO - observed an effect at day 3 for VFA; however, at days 7 and 15, no differences were found. More consistent results on ruminal fermentation were observed using EO of thyme, oregano, cinnamon and garlic or their main components (thymol, carvacrol, cinnamaldehyde and allicin, respectively) (COBELLIS et al., 2016). Kholif et al. (2018) evaluated the effect of an EO blend of capsicum and thymus in ewes with a diet of 60:40 concentrate:forage, and found increased ruminal VFA (13.1\%) and increased milk production (11.7\%).

Similarly, most of the EO compounds at high doses have demonstrated their antimicrobial activity by decreasing total VFA concentration (CASTILLEJOS et al., 2006; KAHVAND; MALECKY, 2018). In the present study, the VFA have not been affected, this effect can be explained for the lower doses used. However, it is necessary to study the effect major inclusions to observe the effect on the production of VFA.

The intake, faecal and blood nitrogen and the synthesis of microbial protein were also not affected by the inclusion of EO. The microbial protein in the rumen is maximised when the ratio of available energy (fermentable organic matter) to protein (nitrogen) is optimised. When there is an excess of nitrogen relative to energy, or high $\mathrm{N}$ degradation for deamination in the rumen, ruminal ammonia concentration increases (BACH et al., 2005). Blood urea nitrogen (BUN) is highly correlated with ruminal ammonia (HAMMOND, 1997). In this study, the effect of EO inclusions of A. occidentale and R. communis on $\mathrm{NH} 3$ and BUN was not observed. Nevertheless, levels above $2 \mathrm{~g}$ EO animal day ${ }^{-1}$ presented a quadratic effect $(\mathrm{P}<$ 0.05 ) in the efficiency of microbial protein synthesis (EMPS. Like monensin, EO have an effect on the hyper-ammonia producing bacteria, which can be helpful in decreasing $\mathrm{N}$ losses (SZUMACHERSTRABEL; CIEŚLAK, 2012).

The allantoin:purine derivatives ratio average was $80 \%$. This value was consistent with the ratio found by (CHEN; GOMES, 1992), who considered that the proportion of allantoin in purine derivatives ranges from 80 to $85 \%$. In relation to the proportion of uric acid in the purine derivatives, Chen and Gomes (1992) considered the ideal value to be 15 to $20 \%$, which is considered constant in one animal, but variable among the animals. In this experiment, the ratio of uric acid to purine derivatives was $20.4 \%$. The mean values for microbial protein synthesis efficiency of $211.6 \mathrm{~g} \mathrm{TDN} \mathrm{kg}^{-1}$ were above the NRC requirement of $130 \mathrm{~g} \mathrm{TDN} \mathrm{kg}^{-1}$ (2006).

\section{Conclusions}

The essential oils of $A$. occidentale and $R$. communis in high grain diets for beef cattle can replace monensin without affecting intake, digestibility, ruminal fermentation or synthesis of microbial proteins. Levels above $2 \mathrm{~g}$ animal day ${ }^{-1}$ of essential oils presented effects on ruminal $\mathrm{pH}$ and in the efficiency of microbial protein synthesis. Further studies are necessary to evaluate the level in $\mathrm{g} \mathrm{day}^{-1}$ to reach the potential of these essential oils in diet to avoid negative effects in ruminal microbiota.

\section{References}

AHMED, M. G.; EL-ZARKOUNY, S. Z.; EL-SHAZLY, K. A.; SALLAM, S. M. A. Impact of essential oils blend on methane emission, rumen fermentation characteristics and nutrient digestibility in barki sheep. Journal of 
Agricultural Science, Cambridge, v. 6, n. 7, p. 144156, 2014. Available at: http://www.ccsenet.org/journal/ index.php/jas/article/view/35365. Accessed at: 1 sept. 2018. DOI: $10.5539 /$ jas.v6n7p144

ANDO, S.; NISHIDA, T.; ISHIDA, M.; HOSODA, K.; BAYARU, E. Effect of peppermint feeding on the digestibility, ruminal fermentation and protozoa. Livestock Production Science, Amsterdam, v. 82, n. 2-3, p. 245-248, 2003. DOI: 10.1016/S0301-6226(03)000125

ASSOCIATION OF OFFICIAL ANALYTICAL CHEMISTS - AOAC. Official Methods of Analysis of AOAC INTERNATIONAL. 20th ed. Rockville: AOAC, 2016.

ATTANASI, O. A.; MELE, G.; FILIPPONE, P.; MAZZETTO, S. E.; VASAPOLLO, G. Synthesis and characterization of novel cardanol based fulleropyrridines. Arkivoc, Gainesville, v. 8, n. 8, p. 69-84, 2009. DOI: 10.1016/j.progpolymsci.2019.02.008

AUMEERUDDY-ELALFI，Z.; GURIB-FAKIM，A.; MAHOMOODALLY, M. F. Chemical composition, antimicrobial and antibiotic potentiating activity of essential oils from 10 tropical medicinal plants from Mauritius. Journal of Herbal Medicine, Munich, v. 6, n. 2, p. 88-95, 2016. DOI: 10.1016/j.hermed.2016.02.002

BABAYEMI, O. J.; DEMEYER, D.; FIEVEZ, V. In vitro rumen fermentation of tropical browse seeds in relation to their content of secondary metabolites. Journal of Animal Feed Sciences, Jabłonna, v. 13, p. 31-34, 2004. Supplement 1. DOI:.22358/jafs/70754/2004

BACH, A.; CALSAMIGLIA, S.; STERN, M. D. Nitrogen metabolism in the rumen. Journal of Dairy Science, Champaign, v. 88, p. E9-E21, 2005. Special Supplement. Available at: http://linkinghub.elsevier.com/retrieve/pii/ S0022030284814095. Accessed at: 1 sept. 2018. DOI: 10.3168/jds.S0022-0302(05)73133-7

BAKKALI, F.; AVERBECK, S.; AVERBECK, D.; IDAOMAR, M. Biological effects of essential oils - A review. Food and Chemical Toxicology, Sand Hutton, v. 46, n. 2, p. 446-475, 2008. DOI: 10.1016/j. fct.2007.09.106

BARRETO, O. T. C.; VALERO, M. V.; ZAWADZKI, F.; RIVAROLI, D. C.; PRADO, R. M. do; LIMA, B. S.; PRADO, I. N. do. Effect of glycerine and essential oils (Anacardium occidentale and Ricinus communis) on animal performance, feed efficiency and carcass characteristics of crossbred bulls finished in a feedlot system. Italian Journal of Animal Science, Abingdon, v. 13, n. 4 , p. $790-797,2014$. DOI: 10.4081/ijas.2014.3492
BEAUCHEMIN, K. A.; MCGINN, S. M. Methane emissions from beef cattle: effects of fumaric acid, essential oil, and canola oil. Journal of Animal Science, Champaign, v. 84, n. 6, p. 1489-1496, 2006. DOI: $10.2527 / 2006.8461489 x$

BELANCHE, A.; DOREAU, M.; EDWARDS, J. E.; MOORBY, J. M.; PINLOCHE, E.; NEWBOLD, C. J. Shifts in the rumen microbiota due to the type of carbohydrate and level of protein ingested by dairy cattle are associated with changes in rumen fermentation. The Journal of Nutrition, Rockvillem v. 142, n. 9, p. 16841692, 2012. DOI: 10.3945/jn.112.159574

BENCHAAR, C.; CALSAMIGLIA, S.; CHAVES, A. V.; FRASER, G. R.; COLOMBATTO, D.; MCALLISTER, T. A.; BEAUCHEMIN, K. A. A review of plant-derived essential oils in ruminant nutrition and production. Animal Feed Science and Technology, Wageningen, v. 145 , n. $1-4$, p. $209-228,2008$. DOI: $10.1016 / j$. anifeedsci.2007.04.014

BENCHAAR, C.; DUYNISVELD, J. L.; CHARMLEY, E. Effects of monensin and increasing dose levels of a mixture of essential oil compounds on intake, digestion and growth performance of beef cattle. Canadian Journal of Animal Science, Toronto, v. 86, n. 1, p. 91-96, 2006. Available at: https://www.nrcresearchpress.com/ doi/pdfplus/10.4141/A05-027. Accessed at: 1 sept. 2018. DOI: $10.4141 / \mathrm{A} 05-027$

BENCHAAR, C.; GREATHEAD, H. Essential oils and opportunities to mitigate enteric methane emissions from ruminants. Animal Feed Science and Technology, Wageningen, v. 166-167, p. 338-355, 2011. Number Special. DOI: 10.1016/j.anifeedsci.2011.04.024

BERGEN, W. G.; BATES, D. B. Ionophores: their effect on production efficiency and mode of action. Journal of Animal Science, Champaign, v. 58, n. 6, p. 1465-1483, 1984. DOI: $10.2527 /$ jas $1984.5861465 \mathrm{x}$

BURT, S. Essential oils: their antibacterial properties and potential applications in foods. International Journal of Food Microbiology, Amsterdam, v. 94, n. 3, p. 223-253, 2004. DOI: $10.1016 /$ j.ijfoodmicro.2004.03.022

BUSQUET, M.; CALSAMIGLIA, S.; FERRET, A.; KAMEL, C. Plant extracts affect in vitro rumen microbial fermentation. Journal of Dairy Science, Champaign, v. 89 , n. 2, p. 761-771, 2006. Avaible at: http://linkinghub. elsevier.com/retrieve/pii/S0022030206721373. Accessed at: 1 sept. 2018. DOI: 10.3168/jds.S00220302(06) 72137-3

CASTILLEJOS, L.; CALSAMIGLIA, S.; FERRET, A. Effect of essential oil active compounds on rumen microbial fermentation and nutrient flow in in vitro 
systems. Journal of Dairy Science, Champaign, v. 89, n. 7, p. 2649-2658, 2006. Avaible at: http://linkinghub. elsevier.com/retrieve/pii/S0022030206723414. Accessed at: 1 sept. 2018. DOI: 10.3168/jds.S00220302(06)72341-4

CASTILLEJOS, L.; CALSAMIGLIA, S.; FERRET, A.; LOSA, R. Effects of dose and adaptation time of a specific blend of essential oil compounds on rumen fermentation. Animal Feed Science and Technology, Wageningen, v. 132, n. 3-4, p. 186-201, 2007. DOI: doi.org/10.1016/j. anifeedsci.2006.03.023

CHANEY,A. L.; MARBACH, E. P. Modified reagents for determination of urea and ammonia. Clinical Chemistry, Washington, v. 8, n. 2, p. 130-132, 1962. Available at: http://clinchem.aaccjnls.org/content/ clinchem/8/2/130. full.pdf. Accessed at: 1 sept. 2018.

CHAO, S. C.; YOUNG, D. G.; OBERG, C. J. Screening for inhibitory activity of essential oils on selected bacteria, fungi and viruses. Journal of Essential Oil Research, Abingdon, v. 12, n. 5, p. 639-649, 2000. DOI: /0.1080/10412905.2000.9712177

CHEN, B. X.; METHIESON, J.; DEB HOVEL, F.; REEDS, P. J. Measurement of purine derivative in urine of ruminants using automated methods. Journal of the Science of Food and Agriculture, Hoboken, v. 53, n. 1, p. 23-33, 1990. DOI: 10.1002/jsfa.2740530104

CHEN, X. B.; GOMES, M. J. Estimation of microbial protein supply to sheep and cattle basid on urinary excretion of purine derivatives-an overview of the technical details. Aberdeen: Ed. Rowett Research Institute, 1992. 212 p. (Ocasional Publication).

CHEN, X. B.; MEJIA, A. T.; KYLE, D. J.; ØRSKOV, E. $R$. Evaluation of the use of the purine derivative-creatinine ratio in spot urine and plasma samples as an index of microbial protein supply in ruminants - Studies in Sheep. Journal of Agricultural Science, Cambridge, v. 125, n. 1, p. 137-143, 1995. DOI: 10.1017/S002185960007458X

COBELLIS, G.; TRABALZA-MARINUCCI, M.; YU, Z. Critical evaluation of essential oils as rumen modifiers in ruminant nutrition: a review. Science of the Total Environment, Amsterdam, v. 546, p. 556-568, 2016. DOI: $10.1016 /$ j.scitotenv.2015.12.103

DEWULF, J.; CATRY, B.; TIMMERMAN, T.; OPSOMER, G.; DE KRUIF, A.; MAES, D. Tetracyclineresistance in lactose-positive enteric coliforms originating from Belgian fattening pigs: degree of resistance, multiple resistance and risk factors. Preventive Veterinary Medicine, Amsterdam, v. 78, n. 3-4, p. 339-351, 2007. DOI: $10.1016 /$ j.prevetmed.2006.11.001
DODDS, D. R. Antibiotic resistance: a current epilogue. Biochemical Pharmacology, Amsterdam, v. 134, p. 139146, 2017. DOI: 10.1016/j.bcp.2016.12.005

EVANS, J. D.; MARTIN, S. A. Effects of thymol on ruminal microorganisms. Current Microbiology, New York, v. 41, n. 5, p. 336-340, 2000. DOI: 10.1007/ s002840010145

FUJIHARA, T.; ØRSKOV, E. R.; REEDS, P. J.; KYLE, D. J. The effect of protein infusion on urinary excretion of purine derivatives in ruminants nourished by intragastric nutrition. The Journal of Agricultural Science, Cambridge, v. 109, n. 1, p. 7-12, 1987. DOI: 10.1017/S0021859600080916

GOÑI, P.; LÓPEZ, P.; SÁNCHEZ, C.; GÓMEZ-LUS, R.; BECERRIL, R.; NERÍN, C. Antimicrobial activity in the vapour phase of a combination of cinnamon and clove essential oils. Food Chemistry, Amsterdam, v. 116, n. 4, p. 982-989, 2009. DOI: 10.1016/j.foodchem.2009.03.058

GRENNI, P.; ANCONA, V.; CARACCIOLO, A. B. Ecological effects of antibiotics on natural ecosystems: a review. Microchemical Journal, Amstedam, v. 136, p. 25-39, 2018. DOI: 10.1016/j.microc.2017.02.006

HAMMOND, A. C. Update on BUN and MUN as a guide for protein supplementation in cattle. In: ANNUAL RUMINANT NUTRITION SYMPOSIUM, 3., 1992, Gainesville. Proceeding... Gainesville: University of Florida, 1997. p. 45-54, 1997. Avaible at: http://dairy. ifas.ufl.edu/rns/1997/frns1997.pdf. Accessed at: 1 sep. 2018.

HIMEJIMA, M.; KUBO, I. Antibacterial agents from the cashew Anacardium occidentale (Anacardiaceae) nut shell oil. Journal of Agricultural and Food Chemistry, Washington, v. 39, n. 2, p. 418-421, 1991. DOI: 10.1021/ jf00002a039

JENA, J.; GUPTA, A. K. Ricinus communis linn: a phytopharmacological review. International Journal of Pharmacy and Pharmaceutical Sciences, Bhopal, v. 4, n. 4, p. 25-29, 2012. Available at: https://www.researchgate. net/profile/Jitendra_Jena/publication/235417877 Ricinus_communis_linn_A_phytopharmacological_

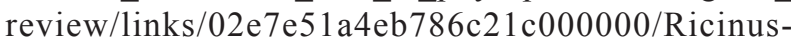
communis-linn-A-phytopharmacological -review.pdf. Accessed at: 1 Sept. 2018

JUTKINA, J.; MARATHE, N. P.; FLACH, C. F.; LARSSON, D. G. J. Antibiotics and common antibacterial biocides stimulate horizontal transfer of resistance at low concentrations. Science of the Total Environment, Amsterdam, v. 616-617, p. 172-178, 2018. DOI: $10.1016 /$ j.scitotenv.2017.10.312 
KADRI，A.; GHARSALLAH， N.; DAMAK， M.; GDOURA, R. Chemical composition and in vitro antioxidant properties of essential oil of Ricinus communis L. Journal of Medicinal Plants Research, Abuya, v. 5, n. 8, p. 1466-1470, 2011. Available at: http:// www.academicjournals.org/JMPR. Accessed at: 1 sept. 2018.

KAHVAND, M.; MALECKY, M. Dose-response effects of sage (Salvia officinalis) and yarrow (Achillea millefolium) essential oils on rumen fermentation in vitro. Annals of Animal Science, Warsaw, v. 18, n. 1, p. 125-142, 2018. DOI: 10.1515/aoas-2017-0024

KHACHATOURIANS, G. G. Agricultural use of antibiotics and the evolution and transfer of antibioticresistant bacteria. Canadian Medical Association, Ottawa, v. 159, n. 9, p. 1129-1136, 1998.

KHOLIF, A. E.; KASSAB, A. Y.; AZZAZ, H. H.; MATLOUP, O. H.; HAMDON, H. A.; OLAFADEHAN, O. A.; MORSY, T. A. Essential oils blend with a newly developed enzyme cocktail works synergistically to enhance feed utilization and milk production of Farafra ewes in the subtropics. Small Ruminant Research, Amsterdam, v. 161, n. 1, p. 43-50, 2018. DOI: 10.1016/j. smallrumres.2018.02.011

KHORSHIDIAN, N.; YOUSEFI, M.; KHANNIRI, E.; MORTAZAVIAN, A. M. Potential application of essential oils as antimicrobial preservatives in cheese. Innovative Food Science and Emerging Technologies, Amsterdam, v. 45, n. 1, p. 62-72, 2018. DOI: 10.1016/j. ifset.2017.09.020

KRAUSE, K. M.; OETZEL, G. R. Understanding and preventing subacute ruminal acidosis in dairy herds: a review. Animal Feed Science and Technology, Wageningen, v. 126 , n. 3-4, p. 215-236, 2006. DOI: 10.1016/j.anifeedsci.2005.08.004

KUBO, I.; NIHEI, K.; TSUJIMOTO, K. Antibacterial action of anacardic acids against methicillin resistant Staphylococcus aureus (MRSA). Journal of Agricultural and Food Chemistry, Washington, v. 51, n. 26, p. 76247628, 2003. DOI: 10.1021/jf034674f

LAMBERT, R. J. W.; SKANDAMIS, P. N.; COOTE, P. J.; NYCHAS, G. J. E. A study of the minimum inhibitory concentration and mode of action of oregano essential oil, thymol and carvacrol. Journal of Applied Microbiology, Oxford, v. 91, n. 3, p. 453-462, 2001. DOI: 10.1046/j.1365-2672.2001.01428.x

LOMONACO, D.; PINHEIRO SANTIAGO, G. M.; FERREIRA, Y. S.; CAMPOS ARRIAGA, Â. M.; MAZZETTO, S. E.; MELE, G.; VASAPOLLO, G. Study of technical CNSL and its main components as new green larvicides. Green Chemestry, Cambridge, v. 11, n. 1, p. 31-33, 2009. DOI: 10.1039/B811504

MAIA, J. G. S.; ANDRADE, E. H. A.; ZOGHBI, M. D. G. B. Volatile constituents of the leaves, fruits and flowers of cashew (Anacardium occidentale L.). Journal of Food Composition and Analysis, Atlanta, v. 13, n. 3, p. 227-232, 2000. DOI: 10.1006/jfca.2000.0894

MCGUFFEY, R. K.; RICHARDSON, L. F.; WILKINSON, J. I. D. Ionophores for Dairy cattle: current status and future outlook. Journal of Dairy Science, Champaign, v. 84, n. Suppl., p. E194-E203, 2001. DOI: 10.3168/jds.S0022-0302(01)70218-4

MCINTOSH, F. M.; WILLIAMS, P.; LOSA, R.; WALLACE, R. J.; NEWBOLD, C. J.; BEEVER, D. A. Effects of essential oils on ruminal microorganisms and their protein metabolism effects of essential oils on ruminal microorganisms and their protein metabolism. Applied and Environmental Microbiology, Washington, v. 69, n. 8, p. 5011-5014, 2003. DOI: 10.1128/ AEM.69.8.5011-5014.2003

MEDJEKAL, S.; BODAS, R.; BOUSSEBOUA, H.; LÓPEZ, S. Evaluation of three medicinal plants for methane production potential, fiber digestion and rumen fermentation in vitro. Energy Procedia, Cambridge, v. 119, p. 632-641, 2017. DOI: 10.1016/j.egypro.2017.07.089

MERTENS, D. R. Gravimetric determination of amylasetreated neutral detergent fiber in feeds with refluxing in beakers or crucibles: collaborative study. Journal of AOAC International, Rockville, v. 85, n. 6, p. 1217-1240, 2002.

MINITAB. MINITAB release 17: statistical software for windows. Minitab Inc, USA, v. 17, 2014.

MUROI, H.; KUBO, I. Bactericidal activity of anacardic acids against Streptococcus mutans and their potentiation. Journal of Agricultural and Food Chemistry, Washington, v. 41, p. 1780-1783, 1993. DOI: 10.1021/jf00034a049

MUROI, H.; NIHEI, K. I.; TSUJIMOTO, K.; KUBO, I. Synergistic effects of anacardic acids and methicillin against methicillin resistant Staphylococcus aureus. Bioorganic and Medicinal Chemistry, Cambridge, v. 12, n. 3, p. 583-587, 2004. DOI: 10.1016/j.bmc.2003.10.046 NAGABHUSHANA, K. S.; SHOBHA, S. V.; RAVINDRANATH, B. Selective ionophoric properties of anacardic acid. Journal of Natural Products, Washington, v. 58, n. 5, p. 807-810, 1995. DOI: 10.1021/np50119a029

NATIONAL RESEARCH COUNCIL - NRC. Nutrient requirements of beef cattle. Seventh Revised Edition. Whashington: The National Academies Press, 2006. p. 248. DOI: $10.17226 / 9791$. 
NEWBOLD, C. J.; MCINTOSH, F. M.; WILLIAMS, P.; LOSA, R.; WALLACE, R. J. Effects of a specific blend of essential oil compounds on rumen fermentation. Animal Feed Science and Technology, Wageningen, v. 114, n. 1-4, p. 105-112, 2004. DOI: 10.1016/j.anifeedsci.2003.12.006

PATRA, A. K.; YU, Z. Effects of essential oils on methane production and fermentation by, and abundance and diversity of, rumen microbial populations. Applied and Environmental Microbiology, Washington, v. 78, n. 12, p. 4271-4280, 2012. DOI: 10.1128/AEM.00309-12

PLAYNE, M. J. Determination of ethanol, volatile fatty acids, lactic and succinic acids in fermentation liquids by gas chromatography. Journal of the Science of Food and Agriculture, Hoboken, v. 36, n. 8, p. 638-644, 1985. DOI: 10.1002/jsfa.2740360803

RIBEIRO, P. R.; CASTRO, R. D. de; FERNANDEZ, L. G. Chemical constituents of the oilseed crop Ricinus communis and their pharmacological activities: a review. Industrial Crops and Products, Amsterdam, v. 91, p. 358376, 2016. DOI: 10.1016/j.indcrop.2016.07.010

RUSSELL, J. B.; STROBEL, H. J. Effect of ionophores on ruminal fermentation. Applied and Environmental Microbiology, Washington, v. 55, n. 1, p. 1-6, 1989.

SANTSCHI, D. E.; CHIQUETTE, J.; BERTHIAUME, R.; MATTE, J. J.; MUSTAFA, A. F.; GIRARD, C. L. Effects of methods of collection and sample preparation on the concentrations of B-vitamins in ruminal fluid of dairy cows. Canadian Journal of Animal Science, Toronto, v. 85, n. 3, p. 417-420, 2005. DOI: 10.4141/ A05-011

SMITH, A. M.; REID, J. T. Use of chromic oxide as an indicator of fecal output for the purpose of determining the intake of pasture herbage by grazing cows. Journal of Dairy Science, Champaign, v. 38, n. 5, p. 515-524, 1955. DOI: 10.3168/jds.S0022-0302(55)95006-2

SNIFFEN, C. J.; O'CONNOR, J. D.; VAN SOEST, P. J.; FOX, D. G.; RUSSELL, J. B. A net carbohydrate and protein system for evaluating cattle diets: I. Ruminal fermentation. Journal of Animal Science, Champaign, v. 70 , n. 11, p. 3562-3577, 1992. DOI: $10.2527 / 1992.70113551 x$

SOLTAN, Y. A.; HASHEM, N. M.; MORSY, A. S.; EL-AZRAK, K. M.; EL-DIN, A. N.; SALLAM, S. M. Comparative effects of Moringa oleifera root bark and monensin supplementations on ruminal fermentation, nutrient digestibility and growth performance of growing lambs. Animal Feed Science and Technology, Wageningen, v. 235, p. 189-201, 2018a. DOI: 10.1016/j. anifeedsci.2017.11.021
SOLTAN, Y.A.; NATEL,A. S.;ARAUJO, R. C.; MORSY, A. S.; ABDALLA, A. L. Progressive adaptation of sheep to a microencapsulated blend of essential oils: ruminal fermentation, methane emission, nutrient digestibility, and microbial protein synthesis. Animal Feed Science and Technology, Wageningen, v. 237, p. 8-18, $2018 \mathrm{~b}$. DOI: 10.1016/j.anifeedsci.2018.01.004

STEINFELD, H.; WASSENAAR, T.; JUTZI, S. Livestock production systems in developing countries: status, drivers, trends. Revue Scientifique et Technique, Paris, v. 25, n. 2, p. 505-516, 2006.

SZUMACHER-STRABEL, M.; CIEŚLAK, A. Dietary possibilities to mitigate rumen methane and ammonia production. In: LIU, G. (Ed.), Grand forks. 2012. p. 348. Available at: https://www.intechopen.com/books/ greenhouse-gases-capturing-utilization-and-reduction/ carbon-dioxide-geological-storage-monitoringtechnologies-review. Acessed at: 1 sept. 2018.

TREVISAN, M. T. S.; PFUNDSTEIN, B.; HAUBNER, R.; WÜRTELE, G.; SPIEGELHALDER, B.; BARTSCH, H.; OWEN, R. W. Characterization of alkyl phenols in cashew (Anacardium occidentale) products and assay of their antioxidant capacity. Food and Chemical Toxicology, Sand Hutton, v. 44, n. 2, p. 188-197, 2006. DOI: $10.1016 /$ j.fct.2005.06.012

VAN DEN BOGAARD, A. E.; STOBBERINGH, E. E. Epidemiology of resistance to antibiotics: links between animals and humans. International Journal of Antimicrobial Agents, Amsterdam, v. 14, n. 4, p. $327-$ 335, 2000. DOI: 10.1016/S0924-8579(00)00145-X

VAN SOEST, P. J.; ROBERTSON, J. B.; LEWIS, B. A. Methods for dietary fiber, neutral detergent fiber, and nonstarch polysaccharides in relation to animal nutrition. Journal of Dairy Science, Champaign, v. 74, n. 10, p. 3583-3597, 1991. Avaible at: https://www. journalofdairyscience.org/article/S0022-0302(91)785512/pdf. Accesed at: 1 sept. 2018.

VIEIRA, C.; FETZER, S.; SAUER, S. K.; EVANGELISTA, S.; AVERBECK, B.; KRESS, M.; REEH, P. W.; CIRILlO, R.; LIPPI, A.; MAGGI, C. A.; MANZINI, S. Pro- and anti-inflammatory actions of ricinoleic acid: Similarities and differences with capsaicin. Naunyn-Schmiedeberg's Archives of Pharmacology, Heidelberg, v. 364, n. 2, p. 87-95, 2001. DOI: $10.1007 / \mathrm{s} 002100100427$

WATKINS, P. J.; FRANK, D.; SINGH, T. K.; YOUNG, O. A.; WARNER, R. D. Sheepmeat flavor and the effect of different feeding systems: a review. Journal of Agricultural and Food Chemistry, Washington, v. 61, n. 15, p. 3561-3579, 2013. DOI: 10.1021/jf303768e 
WILLIAMS, C. H.; DAVID, D. J.; IISMAA, O. The determination of chromic oxide in feces samples by atomic absorption spectrophotometry. The Journal of Agricultural Science, Cambridge, v. 59, n. 3, p. 381-385, 1962. DOI: $10.1017 / \mathrm{S} 002185960001546 \mathrm{X}$

YANG, W. Z.; BENCHAAR, C.; AMETAJ, B. N.; CHAVES, A. V.; HE, M. L.; MCALLISTER, T. A. Effects of garlic and juniper berry essential oils on ruminal fermentation and on the site and extent of digestion in lactating cows. Journal of Dairy Science, Champaign, v. 90 , n. 12 , p. 5671-5681, 2007. DOI: 10.3168/jds.20070369

ZARAI, Z.; CHOBBA, I.; MANSOUR, R.; BÉKIR, A.; GHARSALLAH, N.; KADRI, A. Essential oil of the leaves of Ricinus communis L.: In vitro cytotoxicity and antimicrobial properties. Lipids in Health and Disease, London, v. 11, n. 1, p. 2- 7, 2012. DOI: 10.1186/1476511X-11-102 
